\title{
Sustainable livestock production and the vagaries of climate change
}

Ologhobo, A. D.

Agricultural Biochemistry and Animal Nutrition Unit

Department of Animal Science,

University of Ibadan, Nigeria.

Abstract

Corresponding author: tonyologhobo@yahoo.com;+2348160563595

The climates of the world are distinguished by several factors, including latitude (distance north or south of the equator), temperature (the degree of hotness or coldness of an environment), topography (the shape and height of land features), and distribution of land and sea. Climate change, marked by global warming, is basically the alteration in the balance between incoming and outgoing radiation in the Earth-Atmosphere System. Although climate change is a global phenomenon, its negative impacts are more severely felt by poor people in developing countries who rely heavily on the natural resource base for their livelihoods. Rural poor communities rely greatly for their survival on agriculture and livestock keeping that are amongst the most climate-sensitive economic sectors. Unpredictable climate change with associated disturbances are negatively affecting the livestock industry in Nigeria because as temperatures rise and fall, a wide variety of physiological, behavioural, neuro-endocrinural and molecular responses are initiated in farm animals. This has a range of far reaching effects on livestock production with grave nutritional, health and socio-economic consequences. Given the magnitude of the challenges of climate change and the need to reduce their negative effects, it is imperative to identify mitigation and adaptation measures that are easy to implement and cost effective, in order to stop all human activities that contribute to the problems of climate change and if possible, reverse the trend and attain a significant level of adaptation in vulnerable areas and sectors. The paper builds on this concept and provides strategies for promoting adaptation and mitigation activities for minimizing the effect of climate change in livestock production.

Keywords: Climate Change, Livestock Production, Adaptation, Mitigation Strategies

\section{L'élevage durable et les aléas du changement climatique}

\section{Résumé}

Les climats du monde se distinguent par plusieurs facteurs, notamment la latitude (distance au nord ou au sud de l'équateur), la température (le degré de chaleur ou de froid d'un environnement), la topographie (la forme et la hauteur des caractéristiques du sol) et la distribution des terre et mer. Le changement climatique, marqué par le réchauffement climatique, est essentiellement la modification de l'équilibre entre les rayonnements entrants et sortants dans le système Terre-Atmosphère. Bien que le changement climatique soit un phénomène mondial, ses impacts négatifs sont plus durement ressentis par les pauvres des pays en développement qui dépendent fortement des ressources naturelles pour leurs moyens de subsistance. Les communautés rurales pauvres dépendent beaucoup pour leur survie de l'agriculture et de l'élevage qui font partie des secteurs économiques les plus sensibles au climat. Un changement climatique imprévisible et des perturbations associées affectent négativement l'industrie de l'élevage au Nigéria car, à mesure que les températures augmentent et diminuent, une grande variété de réponses physiologiques, comportementales, neuro-endocrinurales et moléculaires sont initiées chez les animaux 


\section{Sustainable livestock production and the vagaries of climate change}

d'élevage. Cela a une gamme d'effets de grande portée sur la production animale avec de graves conséquences nutritionnelles, sanitaires et socio-économiques. Compte tenu de l'ampleur des défis du changement climatique et de la nécessité de réduire leurs effets négatifs, il est impératif d'identifier des mesures d'atténuation et d'adaptation faciles à mettre en ouvre et rentables, afin d'arrêter toutes les activités humaines qui contribuent aux problèmes climatiques. changer et si possible inverser la tendance et atteindre un niveau d'adaptation significatif dans les zones et secteurs vulnérables. Le document s'appuie sur ce concept et propose des stratégies pour promouvoir les activités d'adaptation et d'atténuation afin de minimiser l'effet du changement climatique sur la production animale.

Mots clés: changement climatique, production animale, adaptation, stratégies d'atténuation

\section{Introduction}

Climate change, marked by global warming, is basically the alteration in the balance between incoming and outgoing radiation in the Earth-Atmosphere System. The awareness of climate change and its possible implications for sustainable development has grown immensely over the past decades and would be of increasing concern in this millennium. There is overwhelming evidence (IFAD, 2015) that climate change is real, that it will become worse, and that the poorest and most vulnerable people will be the worst affected. The Brussels Intergovernmental Panel on Climate Change (IPCC, 2007) acknowledges climate change as one of the factors affecting rural poverty and as one of the challenges that needs to be addressed. To understand the concept of climate change and make decisions about how to respond to it, it is important to distinguish between climate and weather. Weather refers to the condition of the atmosphere at a particular place and time such as temperature, relative humidity, rainfall (precipitation), cloud cover, barometric pressure, and wind speed. Climate on the other hand is the weather experienced by a given location, averaged over several decades. A region's climate tells how hot or cold, wet or dry, windy or still, and cloudy or sunny it generally is. Climate is determined not only by average weather conditions, but also by seasonal changes in those conditions and weather extremes. Thus, for example, a climate can be described as hot and wet year-round, frigid and dry year-round, or warm and rainy in the summer and cold and dry in the winter. Climate change, especially global climate change, is determined from global averages of weather conditions calculated, collated, collected, averaged, and compared over decades (UNEP, 2010). Several reasons have been advanced for the change in global climate but there appear to be a universal consensus that increases in the earth's temperature resulting from increase in greenhouse gases, ozone layer depletion due to production of chlorofluorocarbons, drought and desertification, and rise in sea level, are responsible for the change in weather pattern and seasonal variations (FAO, 2011). Other factors such as irrigation and deforestation can also affect local temperatures and humidity. Average global temperatures have risen considerably and experts anticipate even greater increases in the intensity and prevalence of these changes in the present century. Warmer temperatures mean greater evaporation, and a warmer atmosphere is able to hold more moisture, hence there is more water aloft that can fall as precipitation. In a nutshell: global warming is the cause of climate change and extreme floods, droughts and heat waves, such as Europe's 2015 heat wave, are likely to strike with increasing frequency. Nigeria is particularly lucky that some of the disasters like earthquakes, hurricane flood, tsunamis, and mudslides experienced in other countries have not occurred here but 


\section{Ologhobo}

nonetheless, the effects of climate change have been very devastating. The weather pattern has changed completely from what it used to be and inclement weather such as heavy rainfall, storms, long drought and heat wave, occur on a regular basis in different States. In the last couple of months in Lagos, Ogun and Sokoto States, heavy precipitation resulted in massive flooding of streets, habitations and infrastructure and agricultural lands were completely destroyed (Oluwatayo et al., 2019). The issue of climate change has, therefore become part of the tapestry of the world's political, economic and social relationships. It is now realized that development that does not take into consideration the environment is self-defeating. Thus, Agenda 21 of the 1998 UN conference on Environmental and Development (UNCED), tagged Earth Summit, emphasized that mitigation of climate change must be an integral part of the development process for it to be sustainable (UNCED, 1998).

\section{The greenhouse effect}

Life on earth is made possible by energy from the sun which arrives mainly in the form of visible light. About 30 percent of the sunlight that beams towards the earth is deflected by the outer atmosphere (stratosphere) and scattered back into space. The rest reaches the planet's surface and is reflected upward again as a type of slowmoving energy called infrared radiation. Infrared radiation is carried slowly aloft by air currents and absorbed by naturally occurring gases known as "Greenhouse gases, which slow its escape from the atmosphere" (Figure. 1).

Although Greenhouse gases make up only about onepercent of the Earth's atmosphere, they regulate our climate by trapping heat and holding it in a kind of warm-air blanket that surrounds the planet. The main Greenhouse gases are: carbon dioxide $\left(\mathrm{CO}_{2}\right)$, methane $\left(\mathrm{CH}_{4}\right)$ (from plant decay and other sources), nitrous oxide $\left(\mathrm{N}_{2} 0\right)$, from volcanoes and ozone. Less prevalent but very powerful Greenhouse gases are hydrofluorocarbons ( HFCs), perfluorocarbons (PFCs) and sulphur hexafluoride $\left(\mathrm{SF}_{6}\right)$. Without these gases the earth would be far too cold to sustain our current ecosystem. Scientists estimate that the average temperature on Earth would be colder by approximately 30 degrees Celsius (54 degrees Fahrenheit), far too cold to sustain our current ecosystem environmental prerequisite for life on Earth.

\section{Drivers of climate change}

While the Greenhouse effect is an essential environmental prerequisite for life on Earth, there really can be too much of a good thing. The problems begin when human activities distort and accelerate the natural process by creating more greenhouse gases in the atmosphere than are necessary to warm the planet to an ideal temperature. The traditional practice of the use of fossil fuels (woods and coals) for domestic cooking, burning oil and natural gas is the main source of excess greenhouse gases (Figure 2).

Furthermore, rapidly increasing population, industrial and agricultural activities, contribute significantly to air pollution and climatic changes through the emissions of carbon dioxide and other Greenhouse gases. Humans are burning coal, oil and natural gas at a rate that is much, much faster than the speed at which these fossil fuels were created. 


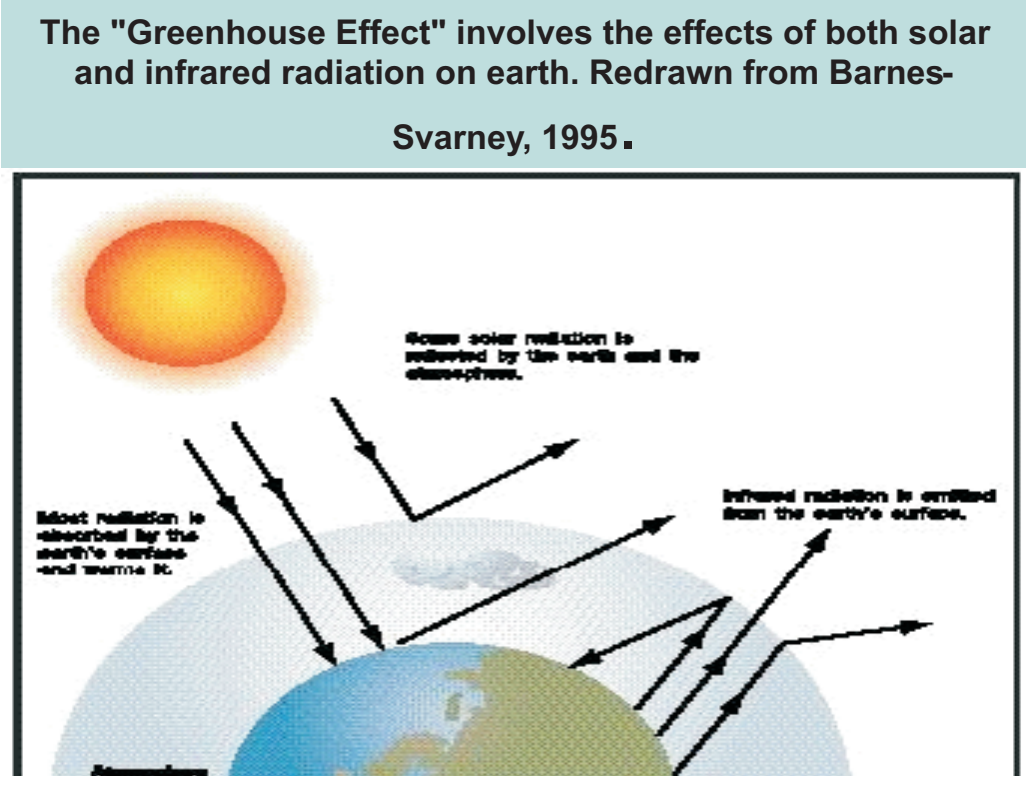

Figure 1: Energy from the sun beams towards the earth

This is releasing the carbon stored in the fuels into the atmosphere and upsetting the carbon cycle, the millennia-old precisely balanced system by which carbon is exchanged between the air, the oceans and land vegetation. Carbon dioxide is responsible for over $60 \%$ of the enhanced Greenhouse effect. Excess methane is emitted from livestock operations and the decomposition of organic waste, nitrogen oxide gases (NO) when gasoline and coal are burned and volatile organic compounds (VOC) are released into the air. Nitrous oxide $\left(\mathrm{N}_{2} \mathrm{O}\right)$ is emitted by internal combustion engines, sewage wastes, and by the burning of solid wastes. Deforestation is another significant source of Greenhouse gases, because fewer trees mean less carbon dioxide conversion to oxygen.

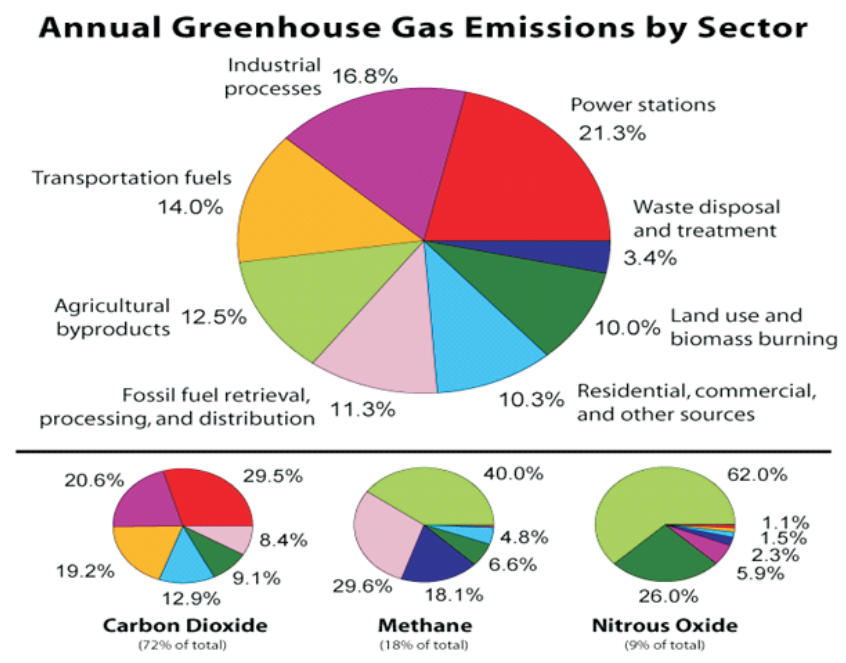

Figure 2: Human Induced GHG from Various Sectors 


\section{Ologhobo}

Drivers of climate change in pictures

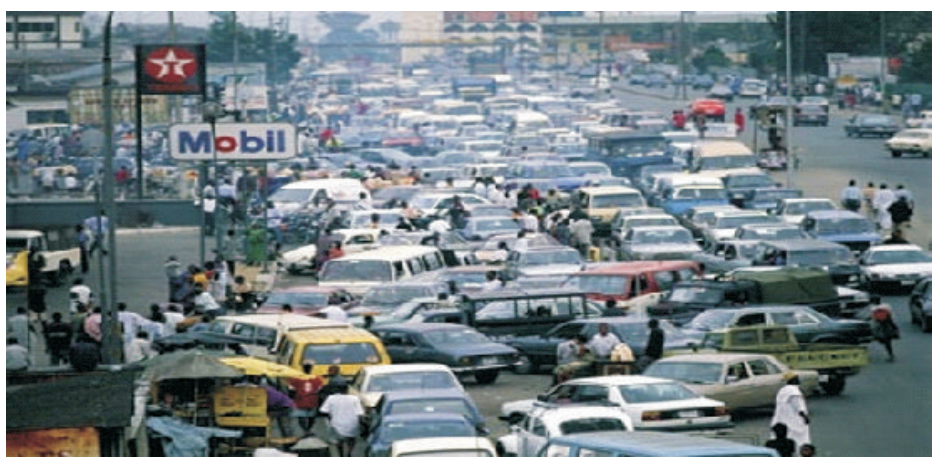

Figure 3: Nitrous Oxide $\left(\mathrm{N}_{2} \mathrm{o}\right)$ is emitted by internal combustion of engines

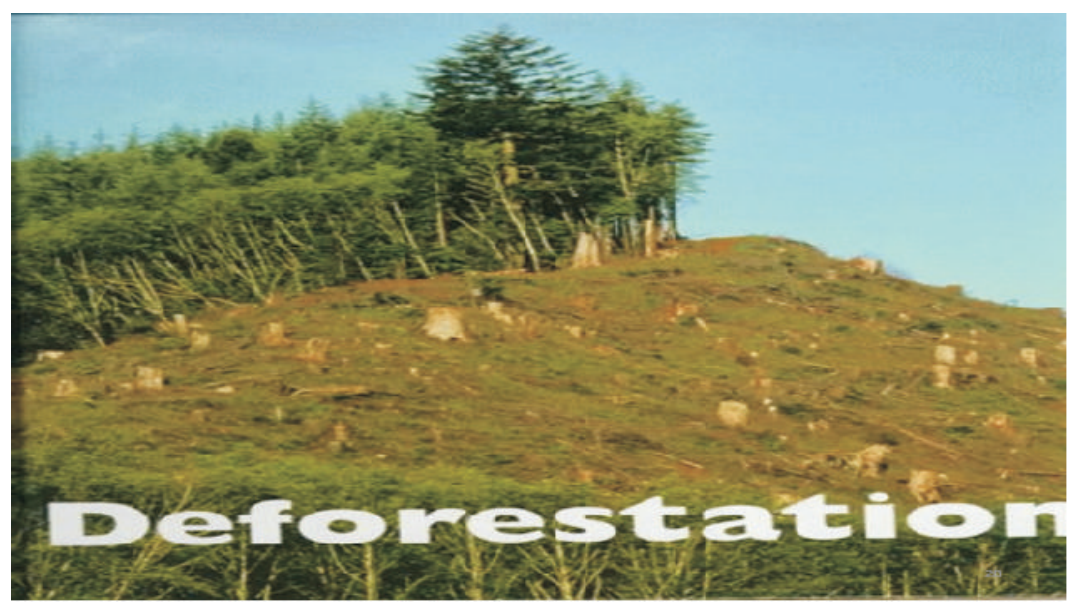

Figure 4: Deforestation

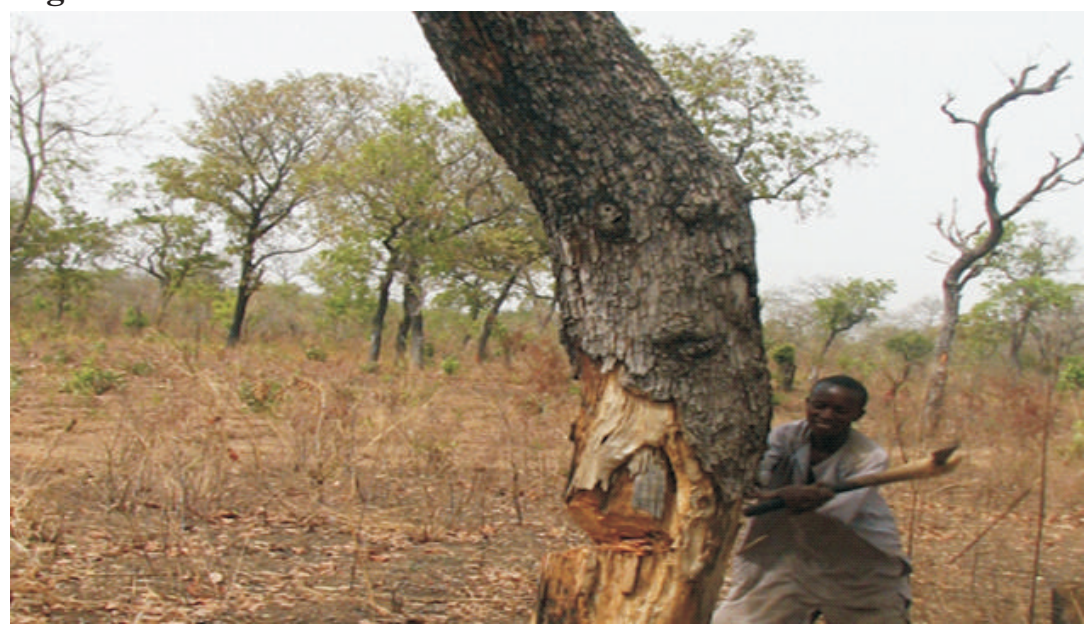

FIGURE 5. Forest Exploitation-1 
Sustainable livestock production and the vagaries of climate change
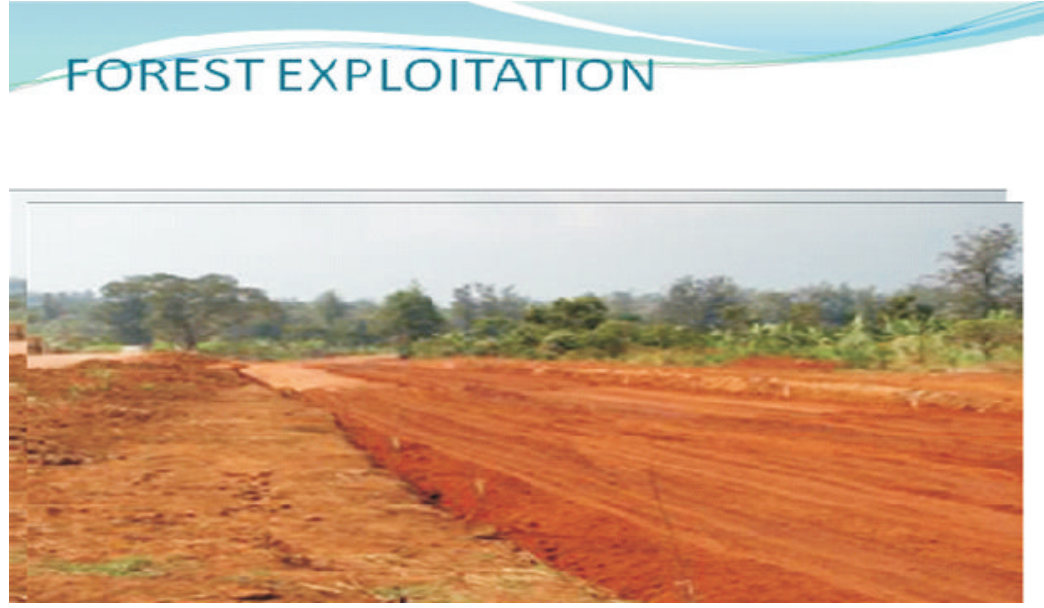

FIGURE. 6. Forest Exploitation-2

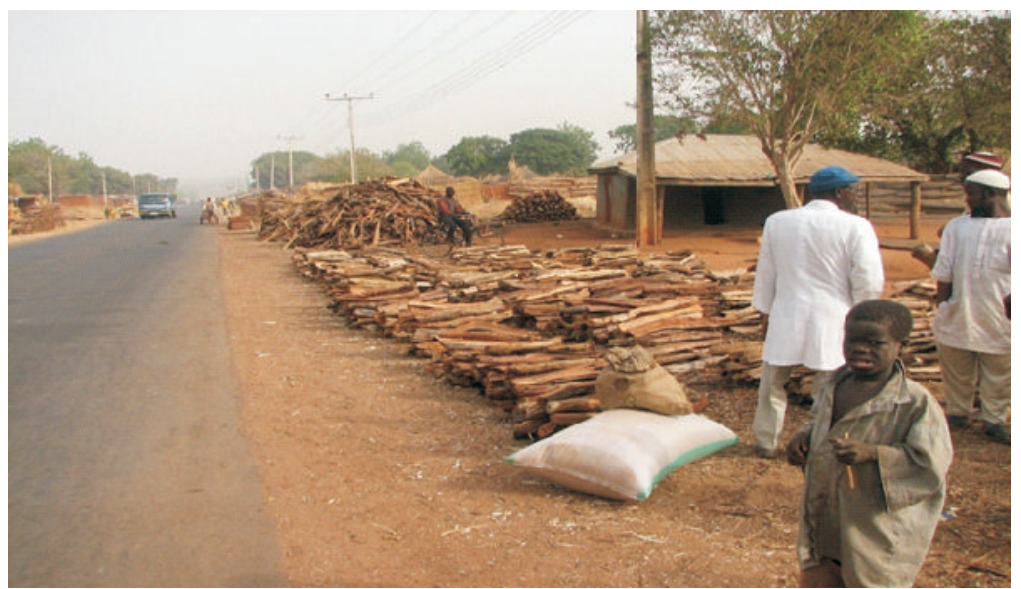

FIGURE. 7. The use of wood as fossil fuel for domestic cooking.

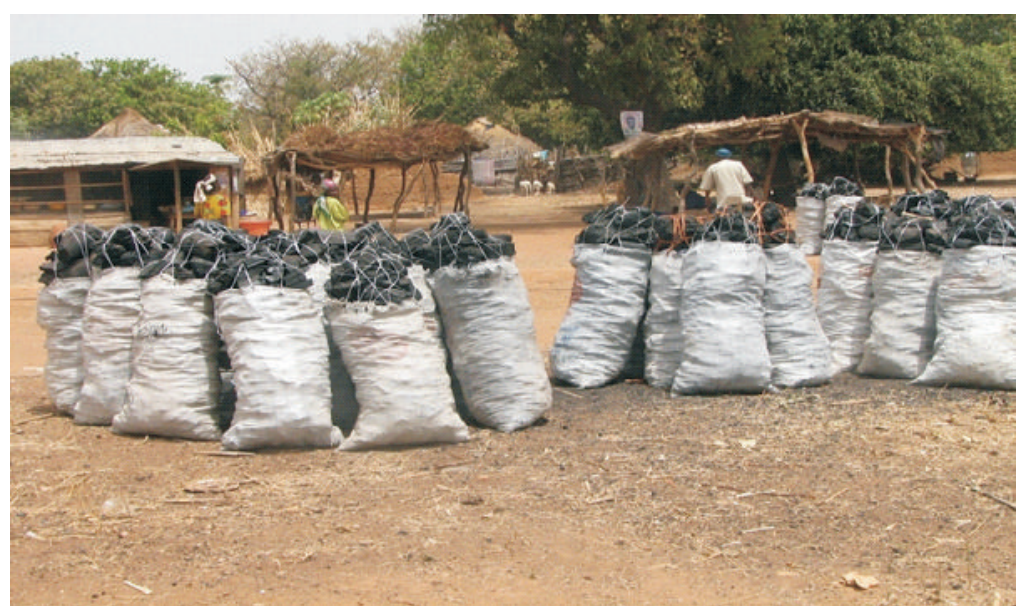

FIGURE. 8. The use of charcoal for domestic cooking 


\section{Ologhobo}

Effects of climate change on livestock production

With sharply increasing demands for animal products in Nigeria and the pressure of livestock production exceeding the absorptive capacity of the environment, the emission and concentration of Greenhouse gases is increasing rapidly with implications for high environmental temperatures and climatic change. This is of concern because the livestock industry plays a very important role in Nigerian agriculture contributing about $12.7 \%$ of the total agricultural GDP (CBN 2006). Apart from its pivotal role in the nation's food security, it provides animal protein for 200 million Nigerians, raw materials for agroindustrial development and a critical contributor to wealth creation and poverty alleviation. In pastoral and agro pastoral systems, livestock is a key asset for poor people, fulfilling multiple economic, social and risk management functions.

Unpredictable climate change with high temperatures and associated disturbances are negatively affecting the livestock industry. A hot environment evokes a combination of behavioral, biochemical and physiological responses in farm animals to maintain body temperature within normal limits. These by implication have a range of far reaching effects on the vulnerability of livestock production systems and their products for rural communities. Losing livestock assets could trigger a collapse into chronic poverty and have a lasting effect on livelihoods. Ironically, animal production is a major contributor to the problems of climate change through emission of human-induced greenhouse gases. Livestock production accounts for approximately $18 \%$, or nearly one-fifth of human-induced GHG emissions, more than the transportation sector. (Steinfeld et al., 2012). There are three main sources of GHG emissions in the livestock production system: the enteric fermentation of animals, manure (waste products) and production of feed and forage (field use) (Miner et al., 2011). Indirect sources of GHGs from livestock systems are mainly attributable to changes in land use and deforestation to create grazing land for livestock. In general, smallholder livestock systems have a smaller ecological footprint than large-scale industrialized livestock operations (Haan et al., 2008). By 2050, global farm animal production is expected to double from present levels and according to FAO (2012) prediction, animal $\mathrm{CH}_{4}$ and $\mathrm{N}_{2} \mathrm{O}$ emissions will increase by $68 \%$ and $75 \%$ respectively due to increased livestock production and increased use of nitrogen fertilizer

\section{The effects of climate change on ruminants}

Ruminant animals produce methane as a byproduct of enteric fermentation in the rumen, converting between $5.5 \%-6.5 \%$ of their energy intake. The ideal ambient temperature for a dairy cow is between $22^{\circ} \mathrm{C}$ and $40^{\circ} \mathrm{C}$. At temperatures above $45^{\circ} \mathrm{C}$, cows have to use energy to cool themselves through heat loss via surface skin and the respiratory tract. High producing cows are the animals most sensitive to heat stress because of their high feed intake. Environmental stress reduces the productivity and health of dairy cattle resulting in significant economic losses. The respiratory rate increases with panting progressing to open-mouth breathing. A consequence is respiratory alkalosis resulting from a rapid loss of carbon dioxide. The cow compensates by increasing urinary output of bicarbonate, and rumen buffering is affected by decreased salivary bicarbonate pool(Cook etal., 2012).

\section{Effects on swine}

Monogastric animals have a level of enteric fermentation in their large intestines, although the rate of conversion of feed energy to methane is limited to between 


\section{Sustainable livestock production and the vagaries of climate change}

$0.6 \%$ and $2.5 \%$ depending on the species. Thermal stress evokes numerous changes in the pigs' metabolism, behaviour, and endocrine system. It is associated with reduced survival of the neonate piglet, poor reproductive performance in sows and boars, and poor growth and carcass quality in finishing pigs. At birth, neonatal pigs have a limited ability to cope with environmental stress (cold and disease) that predispose it to relatively high rates of neonatal morbidity and mortality. In contrast to older animals, the early neonatal piglet does not increase its intake in response to cold temperature. Intake actually decreases during cold exposure, increasing the likelihood of starvation. Unlike the young pig, in which exposure to cold stress poses major health risks, in older pigs, exposure to heat stress hinders performance and productivity. At ambient temperature greater than $35^{\circ} \mathrm{C}$, sufficient feed intake by the sow is of a greater concern for piglet survival because decreased feed intake by lactating sows results in reduced milk production which affects piglet growth negatively. In boars, heat stress has been shown to alter sperm cell count and quality, thus decreasing reproductive efficiency and capabilities. In finisher pigs, heat stress reduces growth rate, alters carcass composition and the value of the final product (Fuller, 2004). Given the associated economic losses due to thermal stress in pigs, continued research on the interactions among thermal stress, nutritional requirements, immunological status, and overall performance are undoubtedly needed and warranted.

\section{Effects on poultry}

Poultry birds are homeotherms and hot environments evoke a combination of behavioral, biochemical and physiological responsesin them. They produce heat to maintain a relatively constant body temperature, which is between $40-42^{\circ} \mathrm{C}$.
Maintaining a constant body temperature is not a problem when air temperature is at least $10-15$ degrees less than body temperature (Ologhobo et al., 2012). As the air temperature approaches body temperature, the birds are no longer able to maintain their body temperature and become susceptible to heat stress. As birds do not have sweet glands to aid heat loss, they lose heat from the skin. When poultry birds are heat stressed:

They try to re-establish their heat balance with the surrounding by changing their normal behavior; They move away from other birds and spend less time engaging in social behavior; They move against cooler surfaces, such as the block walls or into moving air streams; They lift their wings away from their bodies to reduce insulation and expose any areas of skin that have no feathers; Birds pant heavily during heat stress, resulting in increased respiration rate; Water is lost from the lungs when birds pant and so more water needs to be drunk to prevent dehydration; Blood potassium and sodium are depleted with heavy panting, while blood plasma $\mathrm{pH}$, phosphates and chloride levels increase; A rise in blood plasma $\mathrm{pH}$ results in respiratory alkalosis; There is increased cannibalism; Birds in hot environments reduce feed consumption naturally, reducing heat from metabolism. Feed conversion efficiency and growth rate are also reduced; A reduction in appetite is the birds' effort to reduce energy intake in response to increase in the energy of the environment; They drink more water and splash water on their comb and wattles; Urine output increases loss of water and electrolytes also increases causing a distortion in acid-base balance; Egg production drops and egg size reduces; Reduced fertility in breeders due to less mating; Finally they stagger, become lethargic, listless, and comatose and die. 


\section{Ologhobo}

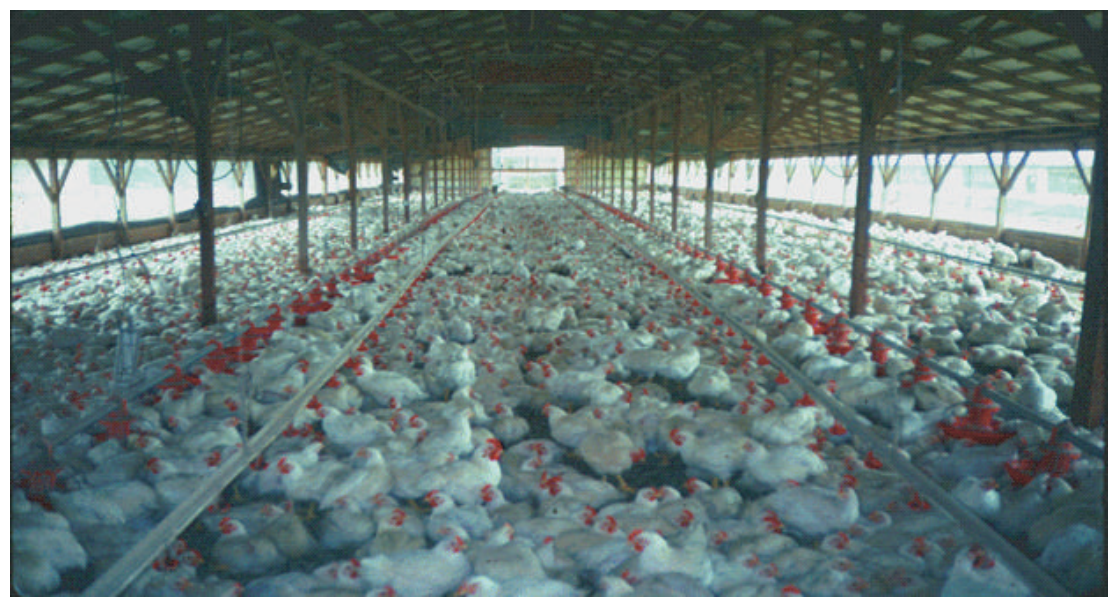

Figure 9: A typical commercial poultry house operating under normal environmental temperature

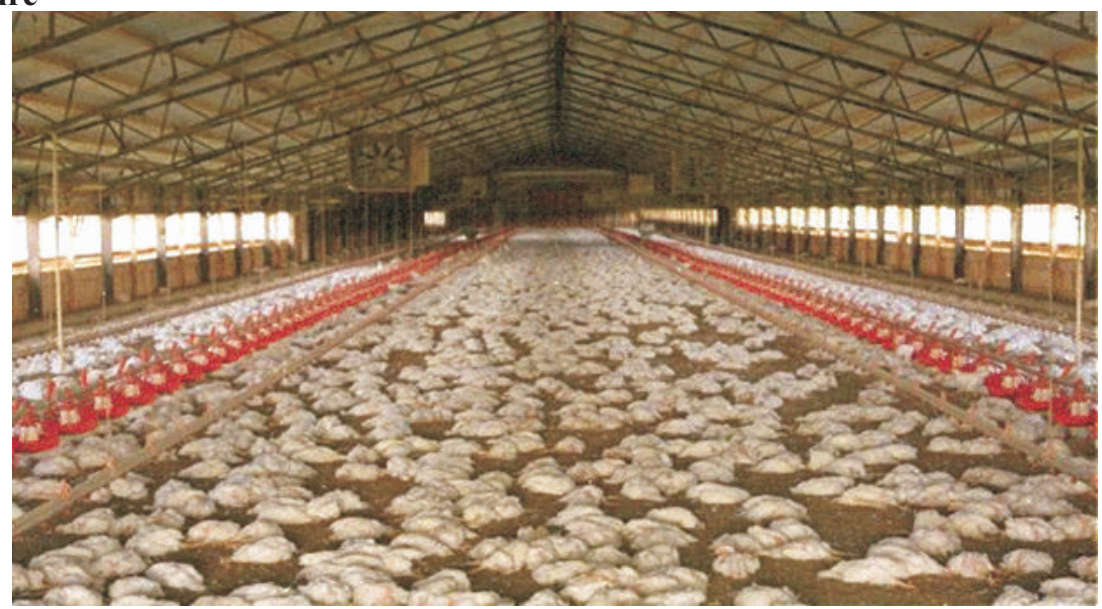

Figure 10: Heat stress may result in complete mortality of poultry birds

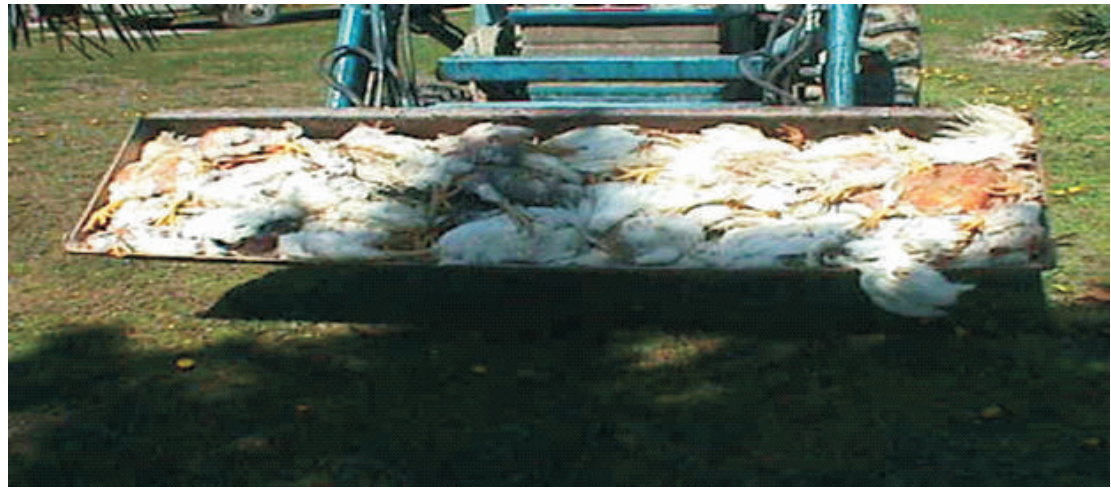

Figure 11: Evacuation of dead birds from the pen is a regular practice during heat wave 


\section{Sustainable livestock production and the vagaries of climate change}

\section{Ways out of the lockjam of climate change} Global warming is getting worse and the emissions of carbon dioxide if not controlled, will continue to grow and the level of the gas in the atmosphere will likely double, or possibly even triple, from preindustrial levels during the 21st century. According to the United Nations, some climate change is already inevitable because of emissions that have occurred since the dawn of the Industrial Age.The basic approaches for responding to climate change have been through mitigation and adaptation strategies. The overall objectives are to stop all human activities that contribute to cause the problem and if possible reverse the trend, and to attain a significant level of adaptation in vulnerable areas and sectors.

\section{Adaptation strategies to cope with climate change}

Adaptation is the ability of human systems to adapt to, cope with change and adjust to the actual or anticipated effect of climate change. Adaptation includes all activities that help people and ecosystems reduce their vulnerability to the adverse impacts of climate change and minimize the costs of natural disasters. Livestock producers have traditionally adapted to various environmental and climatic changes by building on their in-depth knowledge of the environment in which they live. However, the expanding human population, urbanization, environmental degradation and increased consumption of animal source foods have rendered some of those coping mechanisms ineffective (Sidahmed, 2008). In addition, changes brought about by global warming are likely to happen at such a speed that they will exceed the capacity of spontaneous adaptation of both human communities and animal species.

The following have been identified by several experts (FAO, 2008; IPCC, 2010; Bierbaum et al., 2015) as ways to increase adaptation in the livestock sector:

\section{Breeding/Genetic strategies}

This involves selection of breeds of farm animals that will adapt to hot environment and tolerate heat stress. Many local breeds are already adapted to harsh living conditions. Breeding strategies address not only the tolerance of livestock to heat, but also their ability to survive, grow and reproduce in conditions of poor nutrition, parasites and diseases (McMichael et al. 2012). Such measures include: (i) identifying and strengthening local breeds that have adapted to local climatic stress and feed resources and (ii) improving local breeds through cross-breeding with heat and disease tolerant breeds. In the case of poultry, birds with reduced feather mass and those with "Naked neck and frizzle genes" have been found to produce more and have good growth rate at high temperatures. If climate change is faster than natural selection, the risk to the survival and adaptation of the new breed is greater. Developing countries are usually characterized by a lack of technology in livestock breeding that might otherwise help to speed adaptation

\section{Nutritional strategy}

Animals respond to high temperature by reducing feed intake thereby reducing the energy needed from the feed in response to the increase in environmental energy. The reduced feed intake is compensated for by ensuring adequate nutrients (metabolizable energy, amino acids, crude protein, fat, calcium, vitamins and salt) in feed. We now talk of nutrient density and not nutrient level (Goodland, 2007). When an animal is under stress, particularly environmental stress, it excretes electrolytes, acid concentration increases and the body's balance is upset. The body needs a continuous supply of fluids and electrolytes to balance the body fluids in and around the cells. Vitamins and electrolytes especially sodium chloride, potassium bicarbonate and ammonium chloride should therefore be added to the 


\section{Ologhobo}

drinking water to replace those that are lost and to stimulate water consumption. Providing cool water stimulates water intake and helps reduce bird body temperature (OECD/IEA, 2008). Removing feed during the hottest part of the day can be beneficial in reducing heat stress losses, although extreme care needs to be taken when reintroducing the food to avoid sudden surges in bird activity which may in itself cause bird mortality. Intensive feeding systems for monogastric animals, almost exclusively tied to use of cereal grains and soya bean meal, have encouraged replacement of local strains of cereals with more productive hybrids. The meat from non-ruminant herbivores living in natural ecosystems is considered to be a delicacy taste than that from imported 'improved' breeds (and therefore worthy of a higher price) in many tropical countries. For ruminants, interventions include manipulations of the diet to reduce the heat of digestion, metabolism and internal heat load. In terms of feed composition, grass and hay-fed ruminants emit more methane than those consuming grains, legumes and silage. Feeding high-quality forages maximize fibre digestibility. This can be accomplished by substituting soyabean hulls or citrus pulp for forage (Sutherly, 2016).

\section{Management strategy}

Proper risk management mechanisms and preparedness measures need to be put in place to cope with the impacts of more frequent and extreme climatic change. Preparedness measures, early warning systems and other risk mitigation activities such as strengthening infrastructures and forecasting are needed to reduce the impact of severe weather events and prevent loss of livestock. Poor management of livestock production can be disastrous when there is heat wave. When temperature rises above $35^{\circ} \mathrm{C}$, livestock begin to suffer and eventually die. The higher the temperature, the greater is the stress. Usually the first hot period of the season is the most disastrous.Efficient and affordable adaptation practices need to be developed when there is heat wave. These could include:

(i) Monitor the pen environmental temperature and humidity at intervals during the day;

(ii) Check the water lines and filter frequently to ensure unrestricted in-flow of water;

(iii) Provision of shade and water to reduce heat stress from increased temperature;

(iv). Remove manure and litter from the pen more frequently during period of high temperature because of the heat they generate;

(v) When outside temperature reaches $41^{\circ} \mathrm{C}$, ventilation will not help;

(vi) Combination of ventilation and water is the best choice. Fans, foggers, sprinklers, or direct watering of the birds should be used (Figure 12).
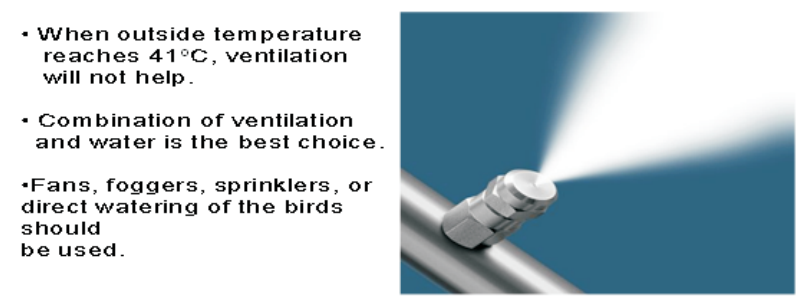

Figure 12: Fans, foggers, sprinklers for watering of birds 


\section{Sustainable livestock production and the vagaries of climate change}

\section{Housing strategy}

The key features of housing that protect birds from climate change are:

1. Insulation

2. Building Design

3. Ventilation

4. Insulated Curtains

5.Stocking Density

\section{Insulation}

Wall or roof Insulation of poultry houses is highly desirable in hot climates to reduce heat that enters the building. On a hot day, the surface of a roof can reach $60^{\circ} \mathrm{C}$. The heat is radiated from the ceiling into the house increasing the heat load on the birds below. Insulation greatly reduces heat transfer through a wall or roof (Fig.13). Insulation is graded on its ability to reduce heat. R-value describes the resistance of the material to heat, the higher the better

\section{Building Design}

In Nigeria, poultry house designs and location have traditionally been a function of birds to be housed and economies of scale without consideration for seasonal weather variations. However, in recent times, modern designs are now considering compliance to environmental control, direction of the wind, radiation from the sun and improved bio-security requirements. The design of the building and its ventilation system, and construction materials, has a profound effect on how well the house performs during hot weather. Roof colour, reflectivity, pitch and orientation, and whether the building is in the shade or not is also a factor which will have a small bearing on solar heat gain.

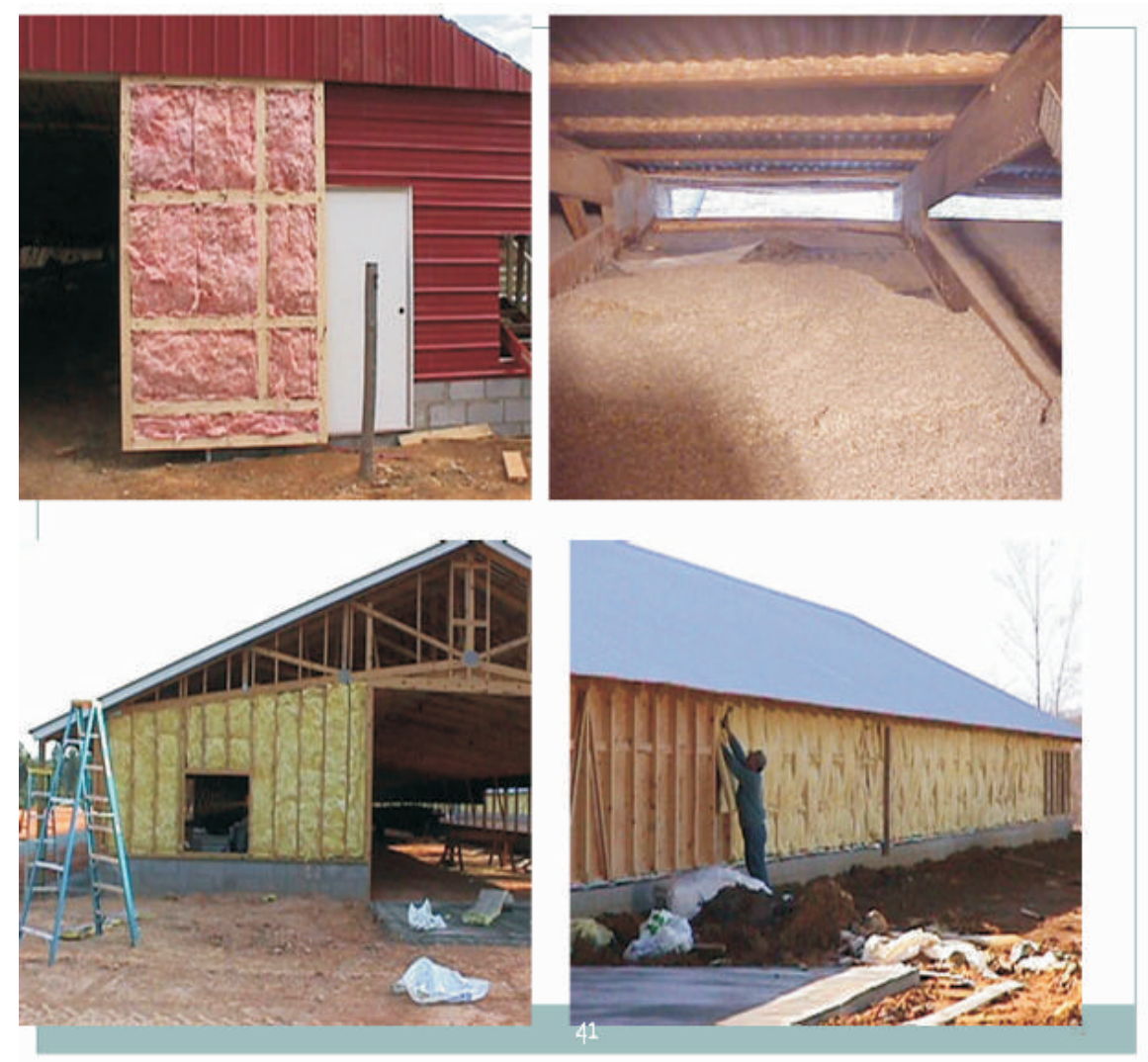

Figure 13: Different insulation materials used for poultry houses 


\section{Ologhobo}

\section{Ventilation}

Ventilation has to do with movement of air in and around a room or building. Achieving adequate air flow in animal pens is absolutely essential in reducing the risk of heat stress. To minimize heat stress, pens should be designed in a way that will aid ventilation, prevent direct sunray (Fig. 14), reduce pen temperature thereby improving the comfort of birds.

\section{Protection from reflected or direct solar radiation}

- Shade

- Trees

- Lawn

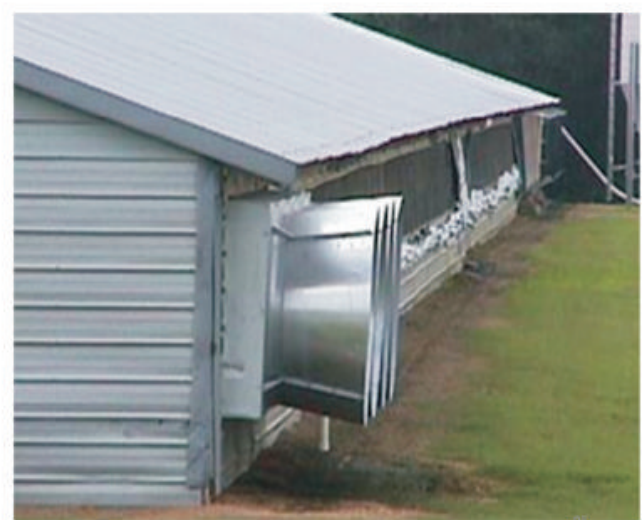

Figure 14: Protection from reflected or direct solar radiation

\section{Insulated curtains}

In most open-sided houses, a curtain should be used to control air movement. Some curtain materials allow light to enter the building. Insulated curtains are also

\section{Curtain on a side wall}
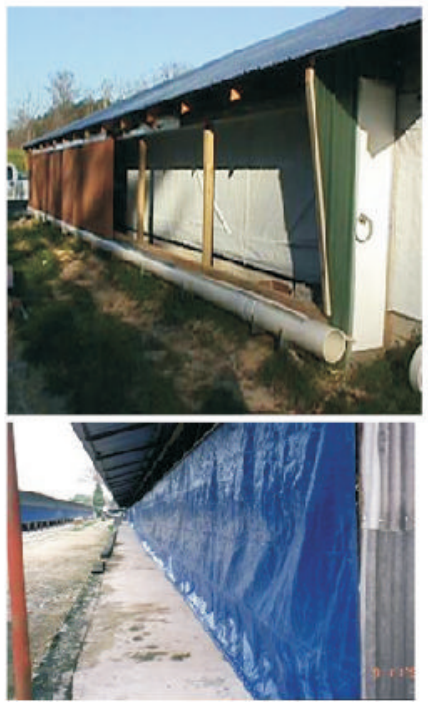

available to reduce heat loss in cold area. Running the ventilation system at or near maximum all night reduces bird body temperature and can improve survivability (Fig. 15).

\section{Solid side wall}

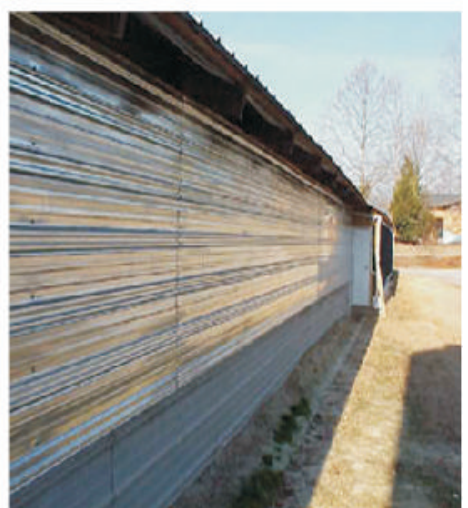

Figure 15: Insulated curtains are used to control air movement 


\section{Stocking density}

The stocking density is also important. If the stocking density is too high for the house and ventilation equipment, temperature may rise dangerously since there will be more metabolic heat being added to the house air than was planned for. When birds are packed together, radiant heat transfer from bird to bird is greater and hot humid air is trapped between the birds. Reducing stocking rate will reduce heat produced in a house, improve air movement around the birds and allow remaining birds time to recover.

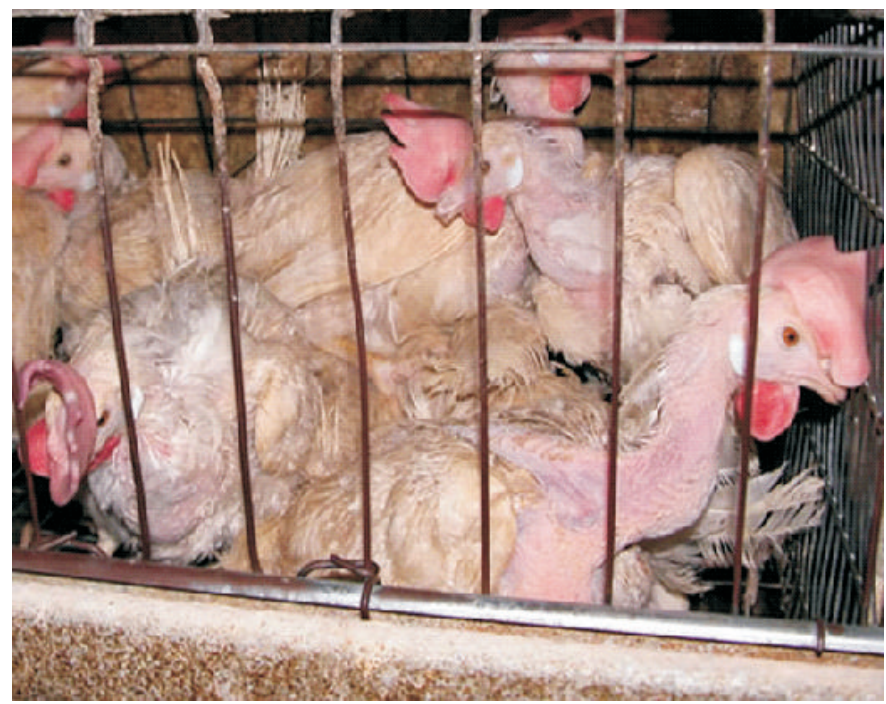

FIGURE. 13. One major cause of heat stress in poultry is housing birds in small cages.

\section{Roof Design}

The roof design should be opened ridged to facilitate the escape of heated air from the pen. The overhead drinking tanks should have reflective colour so as not to absorb heat and should be insulated and covered to avoid direct sun rays.

\section{Roof cooling}

Asbestos roofing sheet should be used instead of zinc. When an un-insulated metal roof is used, sprinkling during high temperature periods is very effective in reducing heat. Roofing overhang should be sufficient to prevent sun rays getting inside the house.

\section{Awareness and education}

Improving the capacity of livestock producers and herders to understand the impacts of climate change on livestock, developing new breeds and genetic types, and improving animal health would support adaptation measures in the long term.
Information about climate change is a crucial component of adaptation. It is important to ensure that knowledge is shared with local communities. An understanding of the patterns of variability of current and projected climate and seasonal forecasts is essential in anticipating shocks and losses, and in enabling external agencies to provide targeted assistance to herders. In addition, training in agro ecological technologies and practices for the production and conservation of fodder improves the supply of animal feed and reduces malnutrition and mortality in herds. This will involve capacity building for livestock keepers.

Community involvement in adaptation strategies

Community involvement in the identification of new solutions is key to ensuring the long-term sustainability of interventions. At present, very few 


\section{Ologhobo}

development strategies promoting sustainable livestock practices, have included measures to support local communities in adapting to or mitigating the effects of climate change. Activities aimed at increasing the resilience of rural communities will be needed to raise their capacity to adapt and to respond to new hazards. At the same time, while small scale livestock keepers, especially poor farmers, are relatively small contributors to Greenhouse gas (GHG) emissions, they have a key role to play in promoting and sustaining a low-carbon rural path through proper agricultural technology and management systems. At the same time, adaptation strategies need to take into account cross-cutting issues (e.g. environment, health, social factors such as increased migration and conflict). Adaptive capacity of livestock producers to climate change will depend largely on the extent to which they can draw on these factors. Those with the least resources will have the least capacity to adapt and will be the most vulnerable.

\section{Livestock mitigation strategies}

Unmitigated climate change will, in the long term, exceed the capacity of natural and human systems to control. Given the magnitude of the challenge to reduce $\mathrm{GHG}$ concentrations in the atmosphere, it is imperative to receive the contribution of all sectors with significant mitigation potential. Agriculture is recognized as a sector with such potential, and farmers, herders, ranchers and other land users could and should be part of the solution (FAO, 2008). Therefore, it is important to identify mitigation measures that are easy to implement and cost effective in order to strengthen the capacity of local actors to adapt to climate change (Oluwatayo et al., 2016). Possible mitigation of $\mathrm{GHG}$ emissions can be achieved through various activities including:

\section{Improved feeding practices}

Improved feeding practices are potential ways to reduce GHG emissions and maximize livestock production and gross energy efficiency. They include phase feeding with balanced rations; penning and grouping strategies to meet nutrient needs by age, sex and size. Ration modifications improve feed digestibility and nutrient utilization, reduce the emissions of nitrogen oxide, methane and carbon dioxide into the atmosphere and minimize phosphorus contamination of water systems. In ruminants, manipulations of the diet reduce the heat of digestion and metabolism and internal heat load. Changes in the rumen environment overtime with respect to microbial population dynamics, $\mathrm{pH}$, and volatile fatty acids especially propionateacetic ratio, have a beneficial effect on the growth and carcass quality. The higher the proportion of concentrate in the diet, is lower than the emission of $\mathrm{CH}_{4}$. Studies with sheep (Adewumi et al., 2015), have shown that the addition of water-washed neem fruit in a concentrate supplement to replace corn bran can reduce enteric methane production by about $60 \%$, improve energy utilisation and nitrogen retention while promoting better growth rates (Nierenberg, 2010).

\section{Grazing management}

One of the major GHG emission contributions from livestock production is from forage or feed crop production and related land use. Proper pasture management through rotational grazing is the most cost-effective way to mitigate GHG emissions from feed crop production. Animals grazing on pastures also help reduce methane $\left(\mathrm{CH}_{4}\right)$ emissions attributable to animal manure because no storage is necessary. Introducing grass species and legumes into grazing lands can enhance carbon storage in soils. Experts have estimated that the soil containscarbon more than twice the quantity in the atmosphere and demonstrated that enhancing carbon sequestration by soils 


\section{Sustainable livestock production and the vagaries of climate change}

could make a potentially useful contribution to climate change mitigation. Promotion of high quality forages in ruminant feed and use of legumes in grazing rations is now being encouraged. To facilitate heat loss, supplemental shades and housing systems should be developed to reduce exposure to solar radiant heat load. Cooling systems such as fans and sprinklers should be supplied to reduce ambient temperature. Cooled cows produce more milk than non-cooled cows (IFOAM, 2014).

\section{Better waste management}

Improving the management of animal waste products through different mechanisms, such as the use of covered storage facilities, is also important. The level of $\mathrm{GHG}$ emissions from manure $\left(\mathrm{CH} 4\right.$ and $\mathrm{N}_{2} \mathrm{O}$ from liquid manure) depends on the temperature and duration of storage. Long-term storage at high temperatures results in higher GHG emissions. In the case of ruminants, pasture grazing is an efficient way to reduce $\mathrm{CH} 4$ emission from manure because no storage is necessary. It is possible not only to mitigate GHG emissions. In order to handle growing volumes of wastes, integrated waste management system should be developed. This approach consists of a coordinated set of actions that reduce pollution, seeks to maximize recovery of re-usable and recyclable materials and protects human health and the environment (Ologhobo, 2014). It comprises:

\section{Waste prevention: The Songhai experience}

Songhai practices an integrated agricultural system where nothing is considered waste. Man, animals, plants, and all that nature has got to offer are harnessed; each relying on the other without friction. This is where everything is re-generated, leaves, stems, and roots are used to produce animal feed, soil mulch, compost manure and aquatic plants, such as water hyacinth, are used to generate gas and purify water. Animal wastes such as poultry droppings, horn, bones, intestines, feathers are equally used for biogas production and compost manures. Rain water is harvested for aquaculture, irrigation and human needs.

\section{Waste re-use}

Once the waste prevention programme has been implemented, the next priority in an integrated waste management approach, is promoting the re-use of products and materials. Re-using materials and products saves energy and water, reduces pollution, and lessens society's consumption of natural resources compared with the use of single-application products and materials

Recycling and recovery of nutrients in solidwastes

Recycling encompasses the full range of resource recovery techniques for converting waste to wealth, including repair, re-manufacture, material recovery and energy conversion of refuse materials. It is technically feasible to recycle a large amount of materials, such as plastics, wood, metals, glass, textiles, paper, cardboard, rubber, ceramics, and leather (Vogler, 2004).

\section{Afforestation strategy}

Afforestation strategy should be promoted by the government in order to save our forests from near extinction by ever increasing human activities. This in turn will contribute to environmental sustainability and the protection of the ecosystem. Trees use carbon dioxide and give off oxygen in its place, which helps to create the optimal balance of gases in the atmosphere. Forests and tree-covers combat land degradation and desertification by stabilizing soils, reducing water and wind erosion and maintaining recycling in soils. Deforestation is a significant source of Greenhouse gas emission, because fewer trees mean less carbon dioxide conversion to oxygen. Large-scale deforestation in the South, particularly in the rain forest zone, has resulted in other problems including 


\section{Ologhobo}

flooding, sheet and gully erosion, as well as siltation of rivers that sometimes constitute the only source of water for domestic use. Deforestation is the removal of all or most of the trees from an area (Popoola, 2010).

\section{Organic farming}

Organic farming has the potential to reduce GHG emissions and sequester carbon (IFOAM, 2004). Raising cattle for beef organically on grass, in contrast to fattening confined cattle on concentrated feed, may emit $40 \%$ less GHGs and consume $85 \%$ less energy than conventionally produced beef (Cerderberg and Stadig, 2003; Fanelli, 2007; Ogino et al., 2007). The meat from non-ruminant herbivores living in natural ecosystems is considered to be a delicacy (and therefore worthy of a higher price) in many tropical countries. Biodiversity will be enhanced by these practices which should be encouraged (e.g., by more research).

\section{Renewable energy alternatives for fossil fuels}

Burning fossil fuels such as natural gas, coal, oil and gasoline raises the level of carbon dioxide in the atmosphere, and carbon dioxide is a major contributor to the Greenhouse effect and global warming. Policies adopted to mitigate climate change will have negative implications for specific sectors, such as the coal, oil and gas industries. Nigeria's economy today remains heavily dependent on the oil sector, which accounts for around $80 \%$ of government revenues, $90-95 \%$ of export revenues and over $90 \%$ of foreign exchange earnings. Such a heavy decline in income would strike at the very heart of Nigeria's economic and social infrastructure, causing a radical scaling down of development plans and entailing huge cutbacks in such vital services as education and health care. It will also affect its ability to invest in future production capacity. It will be in the interest of Nigeria to work out a climate change response development strategy for its own self-preservation and for its survival to be consolidated.

\section{Conclusion}

The Nigerian Livestock Industry needs a policy framework that will enable livestock producers to successfully address the challenges posed by climate change. The crisis is of global proportion and livestock farmers of intensively managed farms with large animal population need to be sensitized about the contribution of farm animals to Greenhouse gas production. Many livestock farmers have no idea what global warming is all about. There is need for a platform for all stakeholders to appraise the current status of livestock production with an attempt to chart a way forward to stimulate sustainable production in compliance with FAO requirements for environmental control. It will also be able to create socio-economic conditions in which successful adoption of environmentfriendly livestock production technologies can be introduced, adapted and practiced by Nigerian livestock farmers.

At the policy level, specific policy statements pertaining to climate change and having implications on the manufacturing sector included, inter alia, that new industries should carry out Environmental Impact Assessment (EIA) as a precondition for issuance of permits. Installation of effluent treatment facilities should be included during the planning process; existing industries should be obliged to install effluent treatment plants and environmental quality control units to monitor performance of the Plants. Recycling of wastes should be promoted and monitoring of effluent discharge from industries should be regular and continuous to ensure compliance with established discharge standards. These laudable policies and institutional arrangements have, however, not yielded the expected results particularly because of weak 
enforcement. Other constraints to implementation of relevant policies include inadequate manpower in the area of integrated environmental management, insufficient political will, inadequate and mismanaged funding, inadequate awareness of the populace on the importance of many environmental issues, and 'top-down' approach in the planning and implementation of environmental-related

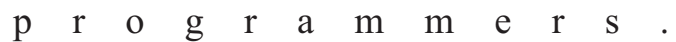
Finally, long term studies on national and regional climate should be embarked upon and religiously pursued. Government should put down adequate funds for animal research that promote environmental sustainability. Policy makers should create political and economic conditions in which the successful adoption of environmental friendly livestock production technologies $\mathrm{c} \mathrm{a} \mathrm{n} \quad \mathrm{tak}$ e $\mathrm{pla} \mathrm{c}$.

\section{References}

Cerderberg, C. and Stadig, M. 2012. System expansion and allocation in life cycle assessment of milk and beef production. Int J Life Cycle Assess. 8:350-356.

Cook, C. W., L. A. Stoddart, and L. E. Harris. 2012. Determining the digestibility and metabolizable energy of winter range plants by sheep. J. Anim. Sci. 11:578.

FAO, 2011. Food and Agriculture Organization of the United Nations. Desertification. 2011. [[accessed 23 October 2011]].

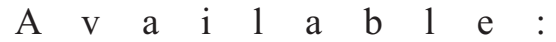
http://www.fao.org/desertification/ default.asp $\square$ la n $g=$ e $n$.

FAO 2012. (Food and Agriculture Organization of the United Nations). Livestock a Major Threat to the Environment: Remedies Urgently Needed. 2012. [[accessed 23 October 2007]]. Available: http://www.fao.org/newsroom/en/ news/2006/1000448/index.html.

Fanelli, 2007. Meat is murder on the environment. New Scientist. 2007. 18 July. [[accessed 23 October $2007]$. p. 15. Available: http://environment.newscientist.co $\underline{\mathrm{m} / \text { article.ns } \mathrm{id}=\mathrm{mg} 19526134.500}$ \& feedId=online-news rss.

Fuller, M. 2004. Enhancing lean meat production in pigs. Feed mix 2 (4): $\begin{array}{lllll}1 & 3 & - & 1 & 6\end{array}$

Goodland, R. 2005. Environmental sustainability in agriculture: Diet matters. Ecol. Econ. 23:189-200.

Haan, C., Steinfeld, H. and Blackburn, H. 2009. Livestock and the Environment: Finding a Balance. Brussels: European Commission Directorate-General for Development. 1997. [[accessed 24 March 2008]]. Available: http://www.fao.org/docrep/x5303e

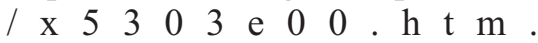

IFAD, 2015. International Fund for Agricultural Development (IFAD). Climate Change: A development challenge. International Funds for Agricultural Development (IFAD), Rome, Italy. http://www.ifad.org.

IFOAM 2014. IFOAM (International Federation of Organic Agriculture Movements). The Role of Organic Agriculture in Mitigating Climate Change. 2014. [[accessed 23 October 2007]]. Available: http://www.ifoam.org/press/positi ons/pdfs/Role_of_OA_migitating c 1 i mate $\mathrm{e}_{-} \mathrm{c}$ h a $\overline{\mathrm{n}} \mathrm{ge} . \mathrm{pd} \mathrm{f}$

IPCC 2007. Intergovernmental Panel on Climate Change. Climate Change: Impacts, Adaptation and Vulnerability. Brussels. 2007a. [[accessed 24 March 2008]].

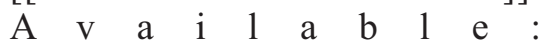
http://www.ipcc.ch/ipccreport s/a r 4 - w g 2 . h t m . 
IPCC 2010. Intergovernmental Panel on Climate Change: Climate Impacts, Adaptation and Vulnerability', Working Group II to the Intergovernmental Panel on Climate Change Fourth Assessment Report, DRAFT technical summary 2006, Geneva: Intergovernmental Panel on $\mathrm{C} 1 \mathrm{i} \mathrm{m}$ a t e $\mathrm{Ch}$ a $\mathrm{g}$ e. McMichael, A. J., Powles, J. W., Butler, C. D. and Uauy, R. 2012. Food, Livestock production, energy, climate change, and health. Lancet.; 370:1253-1263. doi: 10.1016/S0140-6736(07)61256-2. [Online 13 September 2007] $\left[\begin{array}{llllll}\mathrm{P} & \mathrm{u} & \mathrm{b} & \mathrm{M} & \mathrm{e} & \mathrm{d}\end{array}\right]$

Miner, J., Humenik, F. and Overcash, R. 2011. Managing Livestock Wastes to Preserve Environmental Quality. Ames, IA: Iowa University Press; 2

Nierenberg, D. 2010. Rethinking the global meat industry. In: Starke L, editor. State of the World 2006: A Worldwatch Institute Report on Progress Toward a Sustainable Society. New York: W.W. Norton \& Company; 2006. pp. 24-40.

OECD/IEA, 2008. World Energy Outlook: The Role of Energy in Climate Policy, p. $378-404$

Ologhobo, A., Sheku, M. and Adejumo, I. O. 2012. Environmental Consequences of Animal Production: A Review of Strategies for Environmental Pollution Control (ISBN: 978-3-659-14437$0)$. Published by Lambert Academic Publishing, Germany

Ologhobo, A. D. 2014. Overcoming environmental pollution through re- utilization of human and animal wastes as feed ingredients for poultry. RE P O T of NEST/ FORD FOUNDATION
RESEARCH PROJECT Vol. 1, 17

$$
5
$$

Ogino, A., Orito, H., Shimada, K. and Hirooka, H. 2012. Evaluating environmental impacts of the Japanese beef cow-calf system by the life cycle assessment method. Anim Sci J. 2007; 78:424-43.

Oluwatayo, I. B., Sekumade, A. B. and Amao, J. O. 2019. Vulnerability of Agriculture to Climate Change in Nigeria: Implications for Sustainable Staple Food Crop Production, Paper presented at the AERC's Conference on Climate Change and Natural Resource Management, held on 17-18 September, 2016, at the Hotel Intercontinental, Nairobi, Kenya. $\begin{array}{llll}2 & 3 & p & p\end{array}$. Labode, P. 2010. Climate change in Nigeria: trans-sectoral issues and challenges. Climate Change and Desertification: Implications for Tropical Livestock Production. Plenary paper delivered at the International Conference on Climate Change and Desertification - Threat To Food Security in Nigeria at the Usmanu Dan Fodiyo University, Sokoto, $6^{\text {th }}-$ $9^{\mathrm{th}} \quad \mathrm{D}$ e c e m b e r 2010

Steinfeld, H., Gerber, P., Wassenaar, T., Castel, V., Rosales, M. and de Haan, C. 2012. Livestock's Long Shadow: Environmental Issues and Options. Rome: Food and Agriculture Organization of the United Nations; 2006 .

Sutherly, B. 2016. Ohio farms planning to use cows, chickens to generate energy. Dayton Daily News (Dayton, OH). 2007. 22 June. [ [ a c c e s s ed 3 J a nuary 2 [ 0116$]$ ]. A v a i 1 a b 1 e :

UNCED, 1998. UNITED NATIONS C O N F E R E N C E O N 
Sustainable livestock production and the vagaries of climate change

$\begin{array}{llllllllllll} & \mathbf{E} & \mathbf{N} & \mathbf{V} & \mathbf{I} & \mathbf{R} & \mathbf{O} & \mathbf{N} & \mathbf{M} & \mathbf{E} & \mathbf{N} & \mathbf{T}\end{array}$ DEVELOPMENT. (1998). Earth Summiton mitigation of climate change (AGENDA 21). Available: $\mathrm{h}$ t $\mathrm{t} \mathrm{p}:$ / / $\mathrm{p}$ o $\mathrm{s}$ t conflict.unep.ch/publications/UN E P $S$ u d a $n$. p d . UNEP, 2010. United Nations Environment Programme: Post-conflict Environmental Assessment. 2007. [[accessed 24 March 2008]]. Available: http://postconflict.unep.ch/publications/UN E $\mathrm{P}_{-} \mathrm{S} \mathrm{u} \mathrm{a} \mathrm{n} \cdot \mathrm{p} \mathrm{d}$.
Vogler, J. 2004. 'Waste Recycling in Developing Countries: A Review of the Social, Technological, and Market Forces'. In J. Holmes (ed.), Managing Solid Wastes in Developing Countries. New York: $\mathrm{J}$ o h n W i l e y, 244 .

Received: $12^{\text {th }}$ November, 2020 Accepted: $15^{\text {th }}$ February, 2021 